\title{
Pruning Level and Maceration-Fermentation Length Influence on Phenolic Composition of Cabernet Sauvignon in Tarnave Vineyard
}

\author{
Maria ILIESCU ${ }^{1 *}$, Anca BABEŞ²*, Anamaria CĂLUGĂR ${ }^{2}$, Elena-Andreea POP ${ }^{1}$ \\ ${ }^{1}$ Research Station for Viticulture and Enology Blaj, Romania \\ ${ }^{2}$ University of Agricultural Sciences and Veterinary Medicine, Cluj-Napoca, Romania \\ *corresponding author: marina_iliescu@yahoo.com; babesanca@yahoo.com \\ BulletinUASVM Horticulture 77(1) / 2020 \\ Print ISSN 1843-5254, Electronic ISSN 1843-5394 \\ DOI:10.15835/buasvmcn-hort: 2020.0001
}

\begin{abstract}
Technological strategies on vines and winemaking conditions influenced the phenolic composition of wine. Cabernet Sauvignon vines were pruned at 20, 28 and 36 buds/vine. Grapes from each pruning variant were microvinified and macerated for 8 and 16 days. Gallic acid, trans-resveratrol, peonidin-3-monoglycoside and malvidin3-acetyl glycoside were most significantly influenced by pruning level, maceration-fermentation period and interaction between these factors.
\end{abstract}

Keywords: bud loading levels, maceration and fermentation, wine polyphenols

\section{Introduction}

The phenol profile in a wine comes primarily from the grape berries (Urcan et al., 2016) and secondly from winemaking technologies (Casassa, 2017). Phenolic compounds in wine are nonflavonoids and flavonoids (anthocyanins, flavanols, flavonols and dihydroflavonols) (Bora et al., 2018). Fermentation and maceration are the most critical steps in the winemaking process, which affect red wine quality (Setford et al., 2017). During grape growing, some technological strategies may be attempted to manipulate the phenolic composition of red wines (Kyraleou et al., 2015; Kumar et al., 2017). The aim of the study was to analyse the influence of different bud loading level and maceration-fermentation period on phenolic profile of Cabernet Sauvignon wines.

\section{Materials and methods}

The study involved Vitis vinifera cv. Cabernet Sauvignon from Tarnave Vineyard (45 $57^{\prime}$ 46³2' N; 2352'-24⒋' E) during 2017. Vines were trained in Guyot system and applied three variants of pruning level: 20, 28 and 36 buds/vine. The grapes were harvested on full maturity (204 - $214 \mathrm{~g} \mathrm{~L}^{-1}$ sugar content) on the third decade on September. Grapes from each pruning variant were micro-vinified in $20 \mathrm{~L}$ glass containers (three replicates per treatment, $\mathrm{n}=$ 3 ) at $16-17^{\circ} \mathrm{C}$. After 8 and 16 day of maceration- 
Table 1. Multiple analysis of variance (ANOVA) taking as factors the pruning level, macerationfermentation period and interaction between the factors

\begin{tabular}{|c|c|c|c|c|c|c|c|c|c|}
\hline \multirow{2}{*}{$\begin{array}{l}\text { Phenolic composition } \\
\qquad\left(\mathrm{mg} \mathrm{L}^{-1}\right)\end{array}$} & \multicolumn{2}{|c|}{ T1= 20 buds/vine } & \multicolumn{2}{|c|}{$\mathrm{T} 2=36$ buds/vine } & \multicolumn{2}{|c|}{$\begin{array}{c}\text { Control = } 28 \text { buds } / \\
\text { vine }\end{array}$} & \multirow[t]{2}{*}{$\mathrm{A}$} & \multirow[t]{2}{*}{ B } & \multirow[t]{2}{*}{$\mathrm{C}$} \\
\hline & 8 days & 16 days & 8 days & 16 days & 8 days & 16 days & & & \\
\hline \multirow{2}{*}{ Gallic Acid } & $11.96 \pm$ & $17.85 \pm$ & $12.78 \pm$ & $19.47 \pm$ & $11.46 \pm$ & $15.52 \pm$ & \multirow{2}{*}{$* * *$} & \multirow{2}{*}{$* * *$} & \multirow{2}{*}{$* * *$} \\
\hline & $0.31 \mathrm{a}$ & $0.30 \mathrm{e}$ & $0.66 \mathrm{~b}$ & $0.47 \mathrm{~d}$ & $0.15 a$ & $0.09 c$ & & & \\
\hline \multirow{2}{*}{ p-coumaric acid } & $0.90 \pm$ & $0.67 \pm$ & $1.44 \pm$ & $0.69 \pm$ & $1.23 \pm$ & $0.75 \pm$ & \multirow{2}{*}{$* *$} & \multirow{2}{*}{$* *$} & \multirow[b]{2}{*}{ ns } \\
\hline & $0.10 \mathrm{~b}$ & $0.11 \mathrm{a}$ & $0.11 \mathrm{c}$ & $0.10 \mathrm{a}$ & $0.09 \mathrm{bc}$ & $0.17 \mathrm{~b}$ & & & \\
\hline \multirow{2}{*}{ Quercetin } & $0.75 \pm$ & $2.29 \pm$ & $0.90 \pm$ & $2.21 \pm$ & $1.61 \pm$ & $1.68 \pm$ & \multirow[b]{2}{*}{ ns } & \multirow{2}{*}{$* * *$} & \multirow{2}{*}{$*$} \\
\hline & $0.05^{\mathrm{a}}$ & $0.94 \mathrm{c}$ & $0.10 \mathrm{a}$ & $0.02 \mathrm{c}$ & $0.06 \mathrm{~b}$ & $0.11^{\mathrm{b}}$ & & & \\
\hline \multirow{2}{*}{ Trans-resveratrol } & $5.06 \pm$ & $2.54 \pm$ & $6.29 \pm$ & $4.36 \pm$ & $7.53 \pm$ & $2.72 \pm$ & \multirow{2}{*}{$* * *$} & \multirow{2}{*}{$* * *$} & \multirow{2}{*}{$* * *$} \\
\hline & $0.03 \mathrm{~b}$ & $0.51 \mathrm{a}$ & $0.09 c$ & $0.05 b$ & $0.06 \mathrm{~d}$ & $0.16 \mathrm{a}$ & & & \\
\hline \multirow{2}{*}{ Catechin } & $3.49 \pm$ & $8.06 \pm$ & $4.60 \pm$ & $7.45 \pm$ & $4.64 \pm$ & $8.37 \pm$ & \multirow{2}{*}{$*$} & \multirow{2}{*}{$* * *$} & \multirow{2}{*}{$* *$} \\
\hline & $0.11 \mathrm{a}$ & $0.91 d$ & $0.10 \mathrm{~b}$ & $0.11 \mathrm{c}$ & $0.10 \mathrm{~b}$ & $0.07 \mathrm{~d}$ & & & \\
\hline \multirow{2}{*}{ Epicatechin } & $1.77 \pm$ & $2.96 \pm$ & $2.96 \pm$ & $3.86 \pm$ & $3.98 \pm$ & $3.37 \pm$ & \multirow{2}{*}{$* * *$} & $*$ & $* *$ \\
\hline & $0.13 a$ & $0.87 \mathrm{~b}$ & $0.14 \mathrm{~b}$ & $0.12 \mathrm{~d}$ & $0.10 \mathrm{~d}$ & $0.16 \mathrm{c}$ & & T & 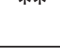 \\
\hline Delfinidine-3- & $3.22 \pm$ & $4.01 \pm$ & $3.23 \pm$ & $3.83 \pm$ & $4.72 \pm$ & $3.20 \pm$ & $* *$ & & \\
\hline monoglycoside & $011 \mathrm{a}$ & $0.32 \mathrm{c}$ & $0.13 a$ & $0.10 \mathrm{~b}$ & $0.05 \mathrm{~d}$ & $0.10 \mathrm{a}$ & *A & ns & F小A \\
\hline Peonidin-3- & $1.78 \pm$ & $1.54 \pm$ & $1.16 \pm$ & $1.18 \pm$ & $2.57 \pm$ & $1.27 \pm$ & & & $* * *$ \\
\hline monoglycoside & $0.12 \mathrm{e}$ & $0.22 \mathrm{~d}$ & $0.14 \mathrm{a}$ & $0.05 b$ & $0.08 \mathrm{f}$ & $0.03 c$ & 皮 & 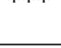 & 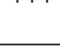 \\
\hline Petunidin-3- & $3.48 \pm$ & $4.89 \pm$ & $3.31 \pm$ & $3.53 \pm$ & $4.55 \pm$ & $3.15 \pm$ & $* * *$ & & \\
\hline monoglycoside & $0.06 \mathrm{~b}$ & $0.11 \mathrm{c}$ & $0.11 \mathrm{ab}$ & $0.12 \mathrm{~b}$ & $0.12 \mathrm{bc}$ & $0.05 a$ & 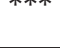 & ns & 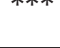 \\
\hline Malvidin-3- & $31.00 \pm$ & $25.95 \pm$ & $27.09 \pm$ & $23.37 \pm$ & $29.27 \pm$ & $24.31 \pm$ & $* *$ & ** & \\
\hline monoglycoside & $3.00 \mathrm{~d}$ & $0.48 \mathrm{bc}$ & $0.41 \mathrm{c}$ & $0.01 \mathrm{a}$ & $0.19 \mathrm{~cd}$ & $0.30 \mathrm{~b}$ & Ta & 尓 & ns \\
\hline Peonidin-3- & $1.52 \pm$ & $1.22 \pm$ & $1.39 \pm$ & $1.14 \pm$ & $1.77 \pm$ & $1.14 \pm$ & & $* * *$ & \\
\hline acetylglycoside & $0.18 \mathrm{c}$ & $0.03 \mathrm{ab}$ & $0.15 b c$ & $0.06 a$ & $0.21 \mathrm{~d}$ & $0.03 a$ & ns & 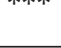 & ns \\
\hline Malvidin-3-acetyl & $12.20 \pm$ & $10.73 \pm$ & $10.82 \pm$ & $9.89 \pm$ & $11.38 \pm$ & $9.96 \pm$ & $* *$ & $* * *$ & $* *$ \\
\hline glycoside & $0.15 \mathrm{c}$ & $0.14 \mathrm{~b}$ & $0.18 \mathrm{~b}$ & $0.11 \mathrm{a}$ & $0.15 \mathrm{bc}$ & $0.07 \mathrm{a}$ & & . & \\
\hline Peonidin-glucoside- & $0.40 \pm$ & $0.41 \pm$ & $0.43 \pm$ & $0.42 \pm$ & $0.50 \pm$ & $0.38 \pm$ & & & \\
\hline coumaryl & $0.13 a$ & $0.04 \mathrm{a}$ & $0.12 \mathrm{a}$ & $0.07 a$ & $0.05 \mathrm{a}$ & $0.05 a$ & ns & ns & ns \\
\hline Malvidin-3-glucoside- & $1.59 \pm$ & $1.19 \pm$ & $1.65 \pm$ & $1.22 \pm$ & $1.84 \pm$ & $1.03 \pm$ & & $* * *$ & \\
\hline coumaryl & $0.10 \mathrm{bc}$ & $0.04 \mathrm{a}$ & $0.02 \mathrm{c}$ & $0.03 \mathrm{ab}$ & $0.11 \mathrm{~d}$ & $0.02 \mathrm{a}$ & ns & $T_{1}$ & The \\
\hline
\end{tabular}

Note: Values are expressed as average \pm standard deviation $(n=3)$. Mean values/row followed by the same letter are not significantly different at $\mathrm{p}<0.05$; A - influence of pruning level on phenolic composition; B - influence of maceration-fermentation period on phenolic composition; $\mathrm{C}$ - influence of interaction between pruning level and maceration-fermentation period; * $\mathrm{p} \leq 0.05$; $^{* *}$ :p $\leq 0.01$; $^{* * *} \mathrm{p} \leq 0.001 ; \mathrm{ns}$ :not significant.

fermentation, the phenolic profile was analysed using high performance liquid chromatography with a Thermo Finnigan Surveyor Thermo Fisher Scientific Inc. (Whatman, USA) chromatographic system and Accuacore PFP column for separation according to Artem et al., 2014.

In order to determine the factor with statistically significant influence on phenolic composition and to evaluate the significance of interactions between factors, a multifactorial variance analysis was made using the pruning level and maceration-fermentation period as factors.

\section{Results and discussions}

The length of maceration (the moment that crushed grapes are in contact with the must) has importance for the extraction of phenolic compounds into the must.

After 16 days of maceration-fermentation, wines samples from $\mathrm{T} 1$ and $\mathrm{T} 2$ had a higher content of polyphenols, while in the control (28 bud/vines) it slowly decreased (Tab. 1). Prolonged maceration results in a significant increase in the concentration of gallic acid, quercitin, catechin and epicatehin as it was previously reported by Kudo and Sodeyama (2002). The decrease in the concentration of some anthocyanins (peonidin3-monoglycoside, malvidin-3-monoglycoside, peonidin-3-acetylglycoside, malvidin-3-acetyl glycoside and malvidin-3-glucoside-coumaryl) can be explained by the absorption by grapes seeds, stems, skins, tannins and wine yeast during maceration (Șener, 2018). 
Several studies found that phenolic composition concentration in grapes may increase or decrease with increasing canopy shade, due to pruning level, without consistency (Kumar et al., 2017). As it may be seen from data of Table 1 , between pruning variants, phenolic profile was significantly affected by this treatment $(p<0.05)$.

In this study, gallic acid, transresveratrol, peonidin-3-monoglycoside and malvidin-3-acetyl glycoside were most significantly influenced by pruning level, maceration-fermentation period and interaction between those factors.

\section{Conclusions}

Tarnave Vineyard is mainly known for white wines. Though red varieties, as Cabernet Sauvignon grapevine were planted in this area for many years, no studies were made regarding pruning level and length of maceration on phenolic profile. Some of phenolic compounds quantified were significantly influenced by pruning level, maceration-fermentation period and interaction between these factors. The results of the present study could be of importance to vineyard managers and winemakers in this wine growing center.

\section{References}

1. Artem V, Geana EI, Antoce AO (2014). Study of phenolic compounds in red grapes and wines from Murfatlar Wine Center. Ovidius University Annals of Chemistry, 25(1): 4752.
2. Bora FD, Bunea C, Coldea T, Călugăr A, Iliescu M, Donici A (2018). The analyses of physicochemical composition, total phenolic content and color of some red wines from Dealu Bujorului Vineyards. Agricultura, 3-4(107-108): 98-104.

3. Casassa LF (2017). Flavonoid Phenolics in Red Winemaking, chapter 6 In: Phenolic Compounds - Natural Sources, Importance and Applications, IntechOpen Acces, DOI: $10.5772 / 67452$

4. Kudo M, Sodeyama M (2002). Weight distribution of red wine polyphenols affected by length of maceration. Am J Enol Vitic, 53, 332A.

5. Kumar AR, Parthiban S, Subbiah A, Sangeetha V (2017). Effect of severity of pruning on yield and quality characters of grapes (Vitis vinifera L.): A Review, Int J Curr Microbiol App Sci, 6(4): 818-835.

6. Kyraleou M, Kallithraka S, Koundouras S, Chira K, Haroutounian S, Spinthiropoulou H, Kotseridis Y (2015). Effect of vine training system on the phenolic composition of red grapes, OENO One, 49(1): 71-84.

7. Setford PC, Jeffery DW, Grbin PR, Muhlack RA (2017). Factors affecting extraction and evolution of phenolic compounds during red wine maceration and the role of process modeling, Trend Food Sci. Tech, 69(A): 106-117.

8. Şener H (2018). Effect of temperature and duration of maceration on color and sensory properties of red wine: A review, S Afr J Enol Vitic 39(2), http://dx.doi. org/10.21548/39-2-3160

9. Urcan DE, Lung ML, Giacosa S, Torchio F, Ferrandino A, Vincenzi S, Río Segade S, Pop N (2016). Phenolic substances, flavor compounds, and textural properties of three native Romanian wine grape varieties. Int J Food Prop, 19(1): 76-98. 